UJBM, Vol. 2, No. 2, July - December 2003, pp 12-20

ISSN 0975-3311 | https://doi.org/10.12725/ujbm.3.2

\title{
MANAGEMENT OF 'STRESS AT JOB' AMONG INDUSTRIAL WORKERS
}

\author{
A.P. Sebastian Titus* \& V. Bastin Jerome**
}

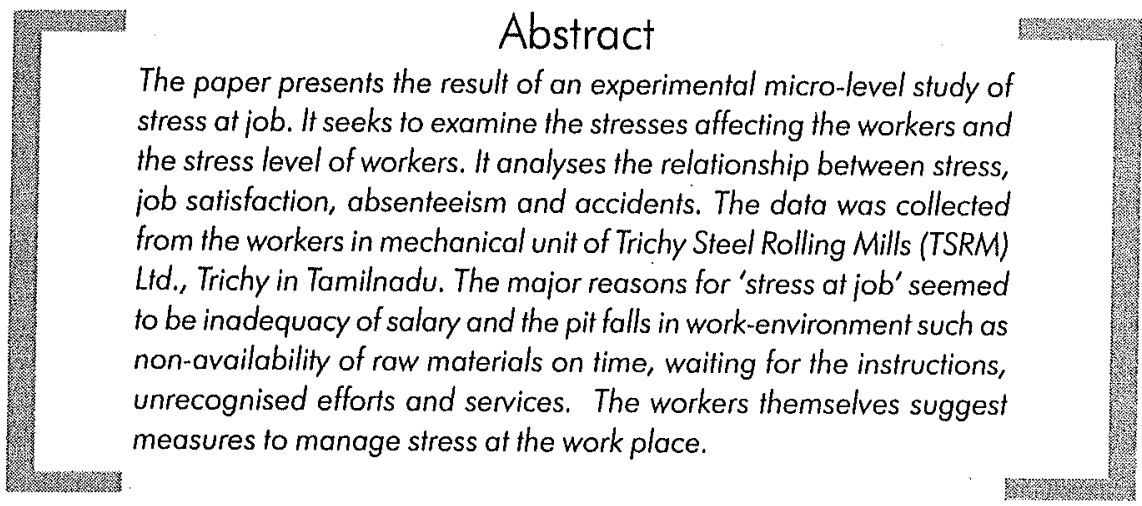

Oxford Dictionary defines stress as "pressure, tension or worry resulting from problems in one's life". Stress is a kind of negative emotion that disturbs the normal functioning of a person affecting his mental and physical health. This definition can be extended

* Lecturer (SS) in Commerce, St.Joseph's College (Autonomous), Tiruchirappalli 620002.

** Post Graduate Student of Commerce, St.Joseph's College (Autonomous), Tiruchirappalli 620002 . 
to the work environment and to define the stress at the job. The employees' well being in general has deteriorated and the potential for stress on the job has increased owing to rush-rush, mobile, urbanized, crowded, on-the-go life style of today. Employees today work for longer hours and meet tighter deadlines. Owing to frequent layoff of the workers they need to do the work, once done by laid-off colleagues. Competition compels the organisation and the workers to cut back on costs. In addition to all these, they have to face the issues of child care, aging parents and meet monthly family demands.

Stress may manifest itself in anxiety. However it is not only just an emotional or psychological phenomenon, it also operates at physiological level. Stress may or may not result in nervous tension for some may bottle-up their stresses. The way the stress is handled differs from person to person. Stress can be positive or negative. For example, promotion to a more challenging job may produce a positive stress. De-promotion or an opportunity missed for promotion will cause a negative stress. The stress that has positive outcomes is called Eustress. The stress that produce negative outcome is referred to as Distress (See Figure 1).

FIGURE 1: A MODEL OF WORK-RELATED STRESS

STRESSORS

\begin{tabular}{|l|}
\hline Physical \\
\hline Noise, Light, Temperature, \\
Vibration, Motion, \\
Pollution, Hazards \\
\hline
\end{tabular}

\section{Psychological}

Boring, Repetitive work, Quantitative underload, Qualitative overload, Qualitative underload, Lack of employee participation, Little responsibility, Limited social contact, Increased responsibility, Increased autonomy, Increased challenge

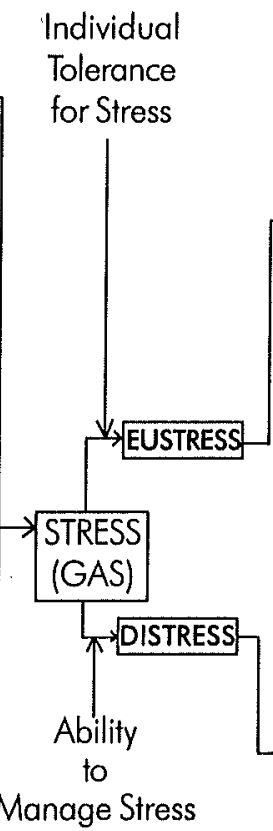

\section{OUTCOMES}

\section{Organisational}

Improved Effectiveness, Goal

Achievement, Improved Human Relation, Team Spirit

\section{Individual}

Increased Motivation, Increased Performance, Increased Job Satisfaction

\section{Organisational}

Absenteeism, Turnover, Decreased Performance, Accidents, Grievances

Individual

Substance, Abuse, Decreased Job Satisfaction, Amity, Anger,

Depression, Alienation, Apathy

Source: Mel E Schnake 1990, 'Human Relations', Merill Publishing W., p.241 
A Stress can be positive up to a level and once it exceeds a particular limit it can become negative (See Figure 2). Working with deadlines will definitely place a stress on a worker. It stirs his energies up to perform at his best. However, if the deadline is too short he may crumble under pressure.

\section{FIGURE 2: LEVEL OF STRESS \\ RELATIONSHIP BETWEEN STRESS AND JOB PERFORMANCE}

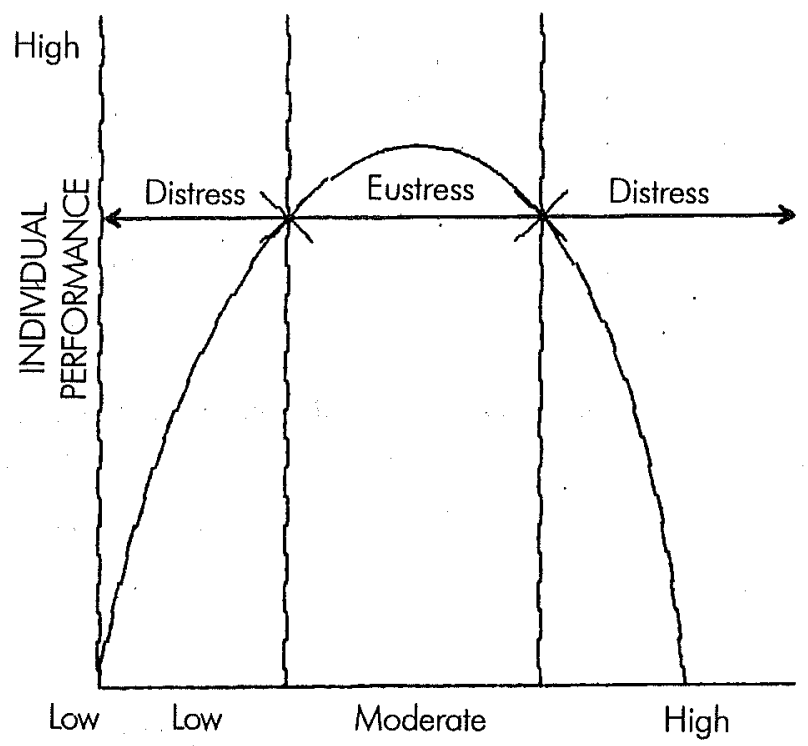

Source: Mel E. Schnake, 1990, 'Human Relations', Merill Publishing W., p.234

Stress is influenced by the stressors. Stressors can include any event, which places environmental demands, internal demands or both that taxes or exceeds the adaptive resources of an individual, social system or tissue system. Job stress is the product of different influences and it can be the result of individual stressors, group stressors, organisational stressors and extra organisational stressors (See Figure 3). The group can give rise to stress, especially when the employee does not feel a sense of togetherness, lacks social support and confronts interpersonal and inter group conflicts. An individual experiences stress as a result of playing number of roles in life. Stress results when the 'time demands' for the work role are incompatible with the 'time pressures' of the family role. 


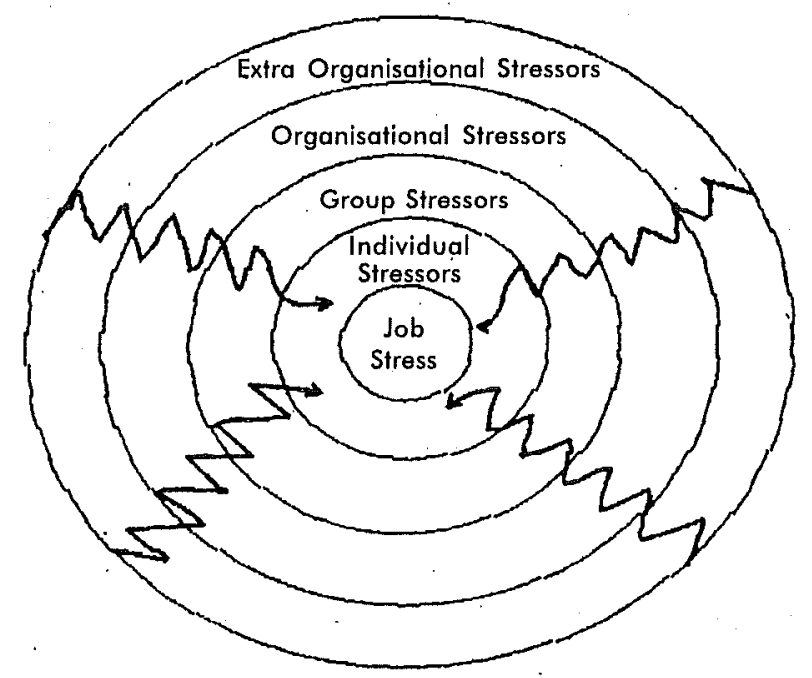

Source: Fred Luthans, 1998, Organizational Behaviour, 8th Edition, Mc-Graw Hill Publication, p. 331.

Work-related stressors are conflict between departments and individuals, time pressure, performance deadlines, staff shortages, too much work, too little work, lack of job security, ambiguous work assignments, lack of recognition, lack of acceptance, poor working conditions, budget cuts and lay offs. The feeling of insecurity may arise owing to fast technological changes, performance evaluation' and isolation from the co-workers. Organisation itself can be the cause for stress. Sometimes they are referred to as macro-level stressors. These macro level stressors may stem from administrative policies and strategies, organisational structure and design, organisational processes and the working conditions (See Figure 4).

The stress can produce physical symptoms, mental and emotional symptoms and behavioural symptoms. Because of stress a person may suffer from physical ailments such as headache, nervousness, shivering, perspiration, blood pressure and palpitation. Irritability, anxiety, depression, loss of sense of humour, inability to concentrate and an inability to make decisions are psychological symptoms. Some people become crazy and indulge in overeating, smoking, drinking and spending. And eventually they become chain smokers, alcoholics or resort to self-destructive behaviour. These are behavioural symptoms. Some of the most common indications of existence of stress are 
FIGURE-4. MACRO - LEVEL ORGANISATIONAL STRESSORS

ADMINISTRATIVE POLICIES AND STRATEGIES

Downsizing,

Competitive pressures,

Merit pay plans,

Rotating work shifts,

Bureaucratic rules,

Advanced technology

\begin{tabular}{|l|}
\hline ORGANISATIONAL STRUCUTRE AND DESIGN \\
\hline Centralisation and Formalisation, \\
Line-Staff conflicts, \\
Specialisation, \\
Role ambiguity and Conflict, \\
No opportunity for promotion, \\
Restrictive and Untrusting culture. \\
\hline ORGANISATIONAL PROCESS \\
\hline Tight Controls, \\
Only downward Communication, \\
Little performance feed back, \\
Centralised decision making, \\
Lack of participation in decisions, \\
Punitive appraised systems \\
WORKING CONDITIONS \\
Crowded work area, \\
Noise, \\
Heat or Cold, \\
Polluted air, \\
Strong Odour, \\
Unsafe and Dangerous conditions, \\
Poor lighting, \\
Physical or mental strain, \\
Toxic chemicals or radiation. .
\end{tabular}

Source: Fred Luthans, 1998, 'Organisational Behaviour', 8th Edition, Mc-Graw Hill Publications, p. 333. 
- Over-reacting or becoming aggressive in conflict situations.

- Loss of interest in personal appearance, relationships or favourite sports and hobbies.

- Sadness, guilt, fatigue and a feeling of helplessness or failure.

- Developing an inferiority/superiority complex

- Loss of interest in discharging work-related duties.

Modern studies of job stress take into account physiological, psychological and behavioural dimensions in unravelling the ramification of stress. The present experimental micro-level study of job stress seeks to examine the stresses affecting the workers and the stress level of workers. It analyses the relationship between stress, job satisfaction, absenteeism and accidents.

For this purpose, the data was collected from the workers in the mechanical unit of Trichy Steel Rolling Mills (TSRM) Ltd., Trichy in Tamilnadu. TSRM was started in the year 1961 and commenced its commercial production from the year 1963. The company is engaged in producing steel bars, rods, ingots, billets and castings. The company is also producing rolling steels in diameters such as $8 \mathrm{MM}_{\mathrm{d}} 10 \mathrm{MM}$, $12 \mathrm{MM}, 16 \mathrm{MM}, 20 \mathrm{MM}$ and $25 \mathrm{MM}$. The company has 340 employees on permanent rolls in addition to 25 employees in managerial cadre. There are 40 persons working on contractual basis. The mechanical unit consists of about 40 employees in number. The main work carried out by this unit is maintenance and assembling of machines. Workers supervise and check at various points in the process of conversion of billets into rolling steels. The mechanical unit of the company was purposely selected for studying the level of stress and the causes of stress. All the floor level workers were covered by the study. The maximum number of these employees constituting $43 \%$ has the work experience of above 16 years. Seventyseven percent of them have not studied beyond $12^{\text {th }}$ standard.

Data were collected through a structured questionnaire. Job satisfaction of workers was measured taking into account the satisfaction level of employees on the quantum of work, output-dependability, opportunities for initiatives in the work place, employees' potentials on job, their appearance and behaviour, quality of work, the co-operation among employees, their communication skills, their level of knowledge about the job and the judgements or decisions made on the job. The stress vulnerability test was conducted for the workers. The tool used for analysis covered the workers' food habits, the normal time spent for sleeping, time spent for family 
members, physical and mental exercises, drinking and smoking habits, religious beliefs, nature of job, nature of relationship and so on.

The following are the important findings of the study.

1. The majority of workers forming 57 percent were found to be satisfied with their work. Seventeen percent of them were 'highly satisfied' with their work and the work place.

2. The 'vulnerability to stress' score revealed that there was no worker who was extremely vulnerable to stress. While 29 percent of the workers were not vulnerable to any stress, 63 percent of the workers were vulnerable to stress. Eight percent of them were seriously vulnerable.

3. The domestic reasons for stress were classified into financial problems, family problems and family care. At least 36 percent of them cited financial problems as the reason for their stress emanating from their domestic front.

4. According to the study the stresses on job are related to work environment, salary, workload, voluntary retirement scheme, career advancement and pollution. The major reasons seemed to be inadequacy of salary and the pit falls in work environment. The pit falls mentioned were non-availability of raw materials on time, waiting for the instruction, unrecognised efforts and services.

5. Stress leads to physical, mental and emotional illness. Twenty two percent of the workers had the problem of low self esteem and anxiety. Twelve per cent of them suffered from emotions of anger and hatred. Eleven percent of them were affected by boredom and depression. About $10 \%$ of them suffered from migraines.

6. The study has also focused on absenteeism and how the work-related stressors has resulted in absenteeism. Only a few ( 8 percent) had taken casual leave above 6 days. Again only 8 percent of them had taken extraordinary leave above 6 days. Only three workers met with major accidents and six workers with minor accidents at the work place.

7. While applying Kendal's tau-b test of correlation it had been found that the relationship between vulnerability test score and job satisfaction level was negative. This implies that those who are vulnerable to stress found their jobs less satisfying. Similarly the number of days absent and the number of accidents were positively correlated with Vulnerability to stress score i.e., the more the employee is vulnerable to stress the more he is prone to accidents and absenteeism. 
The following were the suggestions made by the respondents to reduce stress at domestic and work environment. They are grouped into five categories:

\section{Psychological related suggestions}

1. Set up a counselling centre

2. Patience can reduce stress

3. Spiritual belief can lead to stress reduction

4. Will power, perseverance and self confidence are necessary to cope up with stress

5. Arrange stress-management programmes

\section{Work-related suggestions}

1. Make the raw material available on time

2. Appoint only qualified and experienced workers

3. Avoid unwarranted interruption while engaged on a job

4. Over time must be reasonable

5. Provide for career advancement

6. Hard work and effort should be recognised

\section{Environment related suggestions}

1. Provide sufficient workspace, Install heat reducer at the work place and air cooler in the rest room

2. Take steps to reduce the noise level

\section{Relationship suggestions}

1. Improve relationship among employees

2. Provide opportunities to share joys and sorrows

3. Get suggestions about the work situation at least twice in a month

\section{$\mathrm{V}$ Finance related suggestions}

Increase salary in proportion to the work load

The following are the useful tips the workers and the management can keep in mind to manage the stress:

- Reduce confrontation and conflict duting the work time; Let them wait till the job is over.

- Monitor the food habits and eat healthy 
- Realise the power of own thoughts; thinking can change unhappiness, anger or jealousy into positive energy.

- Suffering from stress is not a sign of weakness. How it is handled is important.

- Create 'patience practice periods'.

- Maintaining a pleasant work environment encourages better output.

- Avoid taking work home.

- Relieve pressure by discussing work-related problems at the work place itself.

- Manage the time effectively at the work place and at home.

In India the industrial workers are not yet fully exposed to stress though stressors in the work environment are definitely increasing. Stress is likely to become an acute problem in the foreseeable future owing to Liberalisation, Privatisation and Globalisation (LPG). It is very important that the management must find and develop the ways and means to help the workers to manage the levels of stress they are experiencing. Stress management facilitates the improved productivity, organisational effectiveness and personal effectiveness.

\section{References:}

1. Mel E. Schnake, 1990, 'Human Relation', Chapter 9, "Managing Organizational Stress" Merill Publishing W., USA, pp.227-250.

2. Baker, 1987, 'Encyclopedia of Psychology', Baker Book Publication, USA. pp. $1121-1122$.

3. Fred Luthans, 1998, 'Organisational Behaviour', $8^{\text {th }}$ edition, Chapter, "Stress: Causes, Effects and copying strategies", Mc-Graw Hill, printed by Thomson Press (India) Ltd., India, pp. 328-354.

4. Consumer Voice, July-August, 2002, 'Tired of Life? Relaxl Take a Break and Manage Your Stress', Vol. 3, No. 4, New Delhi, pp. 32-34. 